\title{
WIND CHARACTERISTICS RECORDED AT THE CZECH CARBON OBSERVATION SYSTEM (CZECOS) SITE RAJEC
}

\author{
SHILPI CHAWLA ${ }^{1,2, *}$, VINH XUAN NGUYEN $1,2,3$, \\ CARLOS P. GUERRA TORRES ${ }^{1,2,4}$, MARIAN PAVELKA ${ }^{1}$, \\ JAN TRUSINA ${ }^{1}$, and MICHAL V. MAREK ${ }^{1}$ \\ ${ }^{1}$ Global Change Research Institute CAS, Bělidla 986/4a, 60300 Brno, Czech Republic \\ ${ }^{2}$ Faculty of Forestry and Wood Technology, Mendel University in Brno, Zemědělská 1, 61300 Brno, Czech Republic \\ ${ }^{3}$ Department of Ecology, Institute of Tropical Biology VAST, 85 Tran Quoc Toan Street, District 3, Ho Chi Minh City, Vietnam \\ 4 Department of Botany, University of Panama P.O. 0824-00077 Panama, Panama \\ *Corresponding author: chawla.s@czechglobe.cz
}

\begin{abstract}
The main aim of this study is to investigate general and temporal characteristics of wind speed and direction at Rajec Ecosystem Station (ES), which is part of the Czech Carbon Observation System (CzeCOS) network and located in the Czech-Moravian highlands in the Czech Republic. Four years (2013-2016) of eddy covariance data recorded in a mature monoculture of spruce (Picea abies) was used to build wind roses and analyse the temporal wind characteristics. The prevailing wind directions at Rajec ES were South-East and North-West and the highland orography in this region does not affect wind flow. Changes in wind direction were recorded each year mainly due to changes in the general atmospheric circulation patterns over Europe. This paper records the occurrence of calm conditions and a threshold of horizontal wind speed $\left(\mathrm{u}\right.$ ) of less than $1 \mathrm{~m} \mathrm{~s}^{-1}$, was used to define calm periods. The average percentage of calm conditions over 4 years was $6 \%$ and when the data was separated into daytime and nighttime occurrence of calm conditions, it was $8 \%$ and $4 \%$, respectively.
\end{abstract}

Keywords: calm conditions; eddy covariance; wind characteristics; wind rose

\section{Introduction}

The eddy covariance (EC) method is a common method used to determine the exchange of energy and matter between a surface and the atmosphere. It is the most direct and accurate approach for investigating turbulent exchange of water vapour and trace components between an ecosystem and the atmosphere (Burba 2013). The EC method determines gas transport by turbulent eddies in real time, which enables one to calculate turbulent fluxes within the atmospheric boundary layer.

It is important to note that changes in the pattern and speed of wind can influence the measurement of fluxes using the EC method. Calm or low wind conditions affect the accuracy of the measurement using an EC system, as the fluxes are often biased under low-wind conditions due to low turbulence (Burba 2013). Wind analysis can help in identifying these problematic periods of low wind intensity. Another application of this type of study can be for silviculture, as practices like thinning of stands result in wind tunnelling and affects the sustainability of forest stands (Mayhead et al. 1975; Cremer et al. 1982; Gardiner et al. 1997). Major thinning in forests increases the roughness of the canopy surface (Cremer et al. 1982), which poses a threat to the trees during gales. Knowledge of the prevailing wind direction in a region can help in planning silviculture treatments in a way that damage of forest stands due to channelling of high winds can be prevented. This will increase the stability of forests and protect them from damage by wind.
The aim of the current study is to investigate the pattern of wind at Rajec Ecosystem Station (ES) and describe the attributes of wind in different seasons/periods of calm $\left(\mathrm{u}<1 \mathrm{~m} \mathrm{~s}^{-1}\right)$ and dynamical $\left(\mathrm{u}>1 \mathrm{~m} \mathrm{~s}^{-1}\right)$ wind conditions over the years 2013-16.

\section{Material and Methods}

\section{Site Description}

The Rajec ES near the town Rajec-Jestrebi is situated in the Czech-Moravian highlands in the Czech Republic. The coordinates of the ES are $49^{\circ} 26^{\prime} 37^{\prime \prime} \mathrm{N}, 16^{\circ} 41^{\prime} 47^{\prime \prime} \mathrm{E}$ and the altitude is $610-625 \mathrm{~m}$ a.s.l. The mean annual temperature over the last few decades (1975-2012) is $7.5 \pm 1.2^{\circ} \mathrm{C}$ and the mean annual precipitation $673 \pm 144 \mathrm{~mm}$. The ES is situated in a mature, currently 117 year old forest consisting of a monoculture of spruce (Picea abies). The height of this stand was $33 \mathrm{~m}$ in 2013 (Markova et al. 2017).

The collection of EC data at Rajec ES started in the year 2012. This ES is part of the national network CzeCOS (Czech Carbon Observation System), the international network ICOS (Integrated Carbon Observation System), national complement of significant infrastructures within ESFRI (European Strategy Forum on Research Infrastructures) and the site is a long-term research station LTER (Long Term Ecological Research).

\section{Instrumentation}

The EC system at Rajec ES is equipped with a 3D sonic anemometer (Gill R3 by Gill Instruments, UK), which 
was used for measuring wind speed and direction and was placed $41 \mathrm{~m}$ above the ground surface which was approximately $8 \mathrm{~m}$ above the surface of the canopy.

\section{Data}

This study uses 4 years of data (2013-2016); Microsoft Excel was used for the analysis. Wind data from the EC system was sampled at $20 \mathrm{~Hz}$ and time-averaged over 30 minute periods. A threshold of horizontal wind speed (u) less than $1 \mathrm{~m} \mathrm{~s}^{-1}$, was used to define calm periods when turbulence was low (Burba 2013).

The four year data set was quality checked, which revealed some gaps in the data. The percentage of missing data was $6.32 \%$ in $2013,7.77 \%$ in $2014,7.05 \%$ in 2015 and $0.11 \%$ in 2016 . The horizontal wind speed data were binned in eight direction classes (Table 1). The percentage of calm conditions $\left(\mathrm{u}<1 \mathrm{~m} \mathrm{~s}^{-1}\right)$ was determined separately for daytime (06:00-18:00), night-time (18:00-06:00), per month and per season. The seasonal characteristics of wind were evaluated for four seasons separately, winter (December-February), spring (March-May), summer (June-August), autumn (September-November). The data was also evaluated for non-growing and growing periods of the year, November-April and May-October respectively. Hajkova et al. (2012) describe May-October as the main growing season of plants in temperate areas in the northern hemisphere.

Table 1 Wind direction classes and their corresponding degree values.

\begin{tabular}{|l|c|}
\hline Direction & Degree \\
\hline North (N) & $0-23$ and 338-360 \\
\hline North-East (NE) & $23-68$ \\
\hline East (E) & $68-113$ \\
\hline South-East (SE) & $113-158$ \\
\hline South (S) & $158-203$ \\
\hline South-West (SW) & $203-248$ \\
\hline West (W) & $248-293$ \\
\hline North-West (NW) & $293-338$ \\
\hline
\end{tabular}

\section{Results and Discussion}

The prevailing wind directions at Rajec ES was northwest (NW) and south-east (SE) over the whole year (Figs. 1 and 2). Four years data revealed that the wind direction on average was $18 \%$ SE, $17 \% \mathrm{NW}, 13 \% \mathrm{~N}$ and $10 \%$ $\mathrm{S}$. This is in accordance with general wind pattern in the Czech-Moravian Highlands, which commonly have NW and SE wind directions (Tolasz et al. 2007).

Seasonal variations in wind direction were recorded (Fig. 3). Tolasz et al. (2007) report that central Europe is mainly influenced by westerly winds and the Czech Republic is among the areas that have dominant effects of the Azores pressure high, Icelandic depression and Siberian high, which effects the wind characteristics during different periods of the year. The observations at ES Rajec show that wind during winter predominantly came from the SW and NE, and shifted direction during spring and summer to NW, N and NE. However, during autumn, $\mathrm{SE}, \mathrm{N}$ and NW were the prevailing wind directions. This can be explained by the general atmospheric circulation patterns over central Europe and potentially by the local circulation, which is modified by the terrain. Border-mountains, individual mountain saddles, valleys and orientation of slopes are some factors that can affect the direction of wind (Tolasz et al. 2007). A similar study to the current one was done by Havránková and Sedlák (2004) for another CzeCOS-ICOS ecosystem station, Bily Kriz, in the Beskydy Mountains in the Czech Republic and it also highlights a strong connection between wind patterns and local topography.

However, a comparison of the results of the current study at ES with those of surrounding meteorological stations at Kucharovice, Svratouch and Brno, operated by the Czech Hydrometeorological Institute (Tolasz et al. 2007), revealed similar wind conditions for all these sites. The other meteorological stations are situated in open terrain well away from significant effects from surrounding barriers. Thus, topography in the surroundings of Rajec ES apparently have only a negligible modifying effect on the wind patterns at ES and therefore we assume that the variations in wind direction during a year are predominantly caused by changes in the regional atmospheric circulation patterns.

For the wind speed analysis, we used different wind speed classes starting from $0-1 \mathrm{~m} \mathrm{~s}^{-1}$ to greater than $12 \mathrm{~m} \mathrm{~s}^{-1}$. At Rajec ES calm wind conditions $\left(<1 \mathrm{~m} \mathrm{~s}^{-1}\right)$ were not very common (Table 2). The percentage of calm wind conditions over a whole year was 5.4, 5.6, 5.8 and $6.7 \%$ for 2013, 2014, 2015 and 2016, respectively. The occurrence of calm conditions at nearby stations (Kucharovice, Svratouch, Brno) was also not very high and similar to that recorded at Rajec ES. It is worth noting that strong winds stronger than $10 \mathrm{~m} \mathrm{~s}^{-1}$ were also not frequent at Rajec ES and occurred more frequently in winter than summer. Thus, this study confirmed that wind speed in most parts of the year is in the range of $1-3 \mathrm{~m} \mathrm{~s}^{-1}$ (Fig. 4).

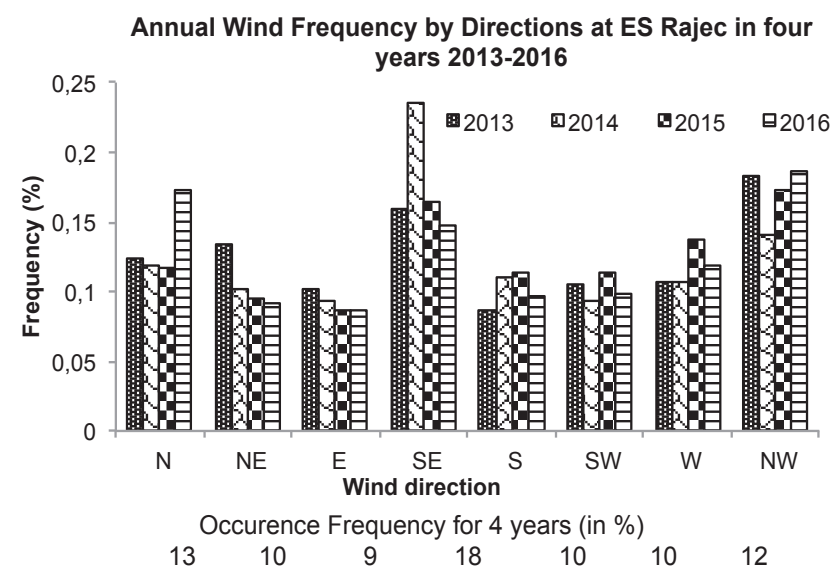

Fig. 1 Annual relative wind frequency by direction recorded each year at the Rajec ecosystem station (2013-16). 
Table 2 Percentage of calm wind conditions $\left(\mathrm{u}<1 \mathrm{~m} \mathrm{~s}^{-1}\right)$ during different periods of a year.

\begin{tabular}{|l|c|c|c|c|c|}
\hline \multicolumn{6}{|c|}{ (All values are percentages of the time during a particular period) } \\
\hline Year & $\mathbf{2 0 1 3}$ & $\mathbf{2 0 1 4}$ & $\mathbf{2 0 1 5}$ & $\mathbf{2 0 1 6}$ & Average \\
\hline Whole year & $\mathbf{5 \%}$ & $\mathbf{6 \%}$ & $\mathbf{6 \%}$ & $\mathbf{7 \%}$ & $\mathbf{6 \%}$ \\
\hline Daytime & $7 \%$ & $8 \%$ & $8 \%$ & $9 \%$ & $8 \%$ \\
\hline Night-time & $4 \%$ & $3 \%$ & $4 \%$ & $5 \%$ & $4 \%$ \\
\hline May-Oct (growing season) & $\mathbf{5 \%}$ & $\mathbf{7 \%}$ & $\mathbf{6 \%}$ & $\mathbf{6 \%}$ & $\mathbf{6 \%}$ \\
\hline$\%$ of day-time & $7 \%$ & $10 \%$ & $8 \%$ & $8 \%$ & $8 \%$ \\
\hline$\%$ of night-time & $2 \%$ & $4 \%$ & $5 \%$ & $3 \%$ & $4 \%$ \\
\hline $\begin{array}{l}\text { Nov-Apr } \\
\text { (non-growing season) }\end{array}$ & $\mathbf{6 \%}$ & $\mathbf{4 \%}$ & $\mathbf{5 \%}$ & $\mathbf{7 \%}$ & $\mathbf{6 \%}$ \\
\hline$\%$ of daytime & $7 \%$ & $6 \%$ & $8 \%$ & $9 \%$ & $7 \%$ \\
\hline$\%$ of night-time & $5 \%$ & $3 \%$ & $3 \%$ & $6 \%$ & $4 \%$ \\
\hline
\end{tabular}
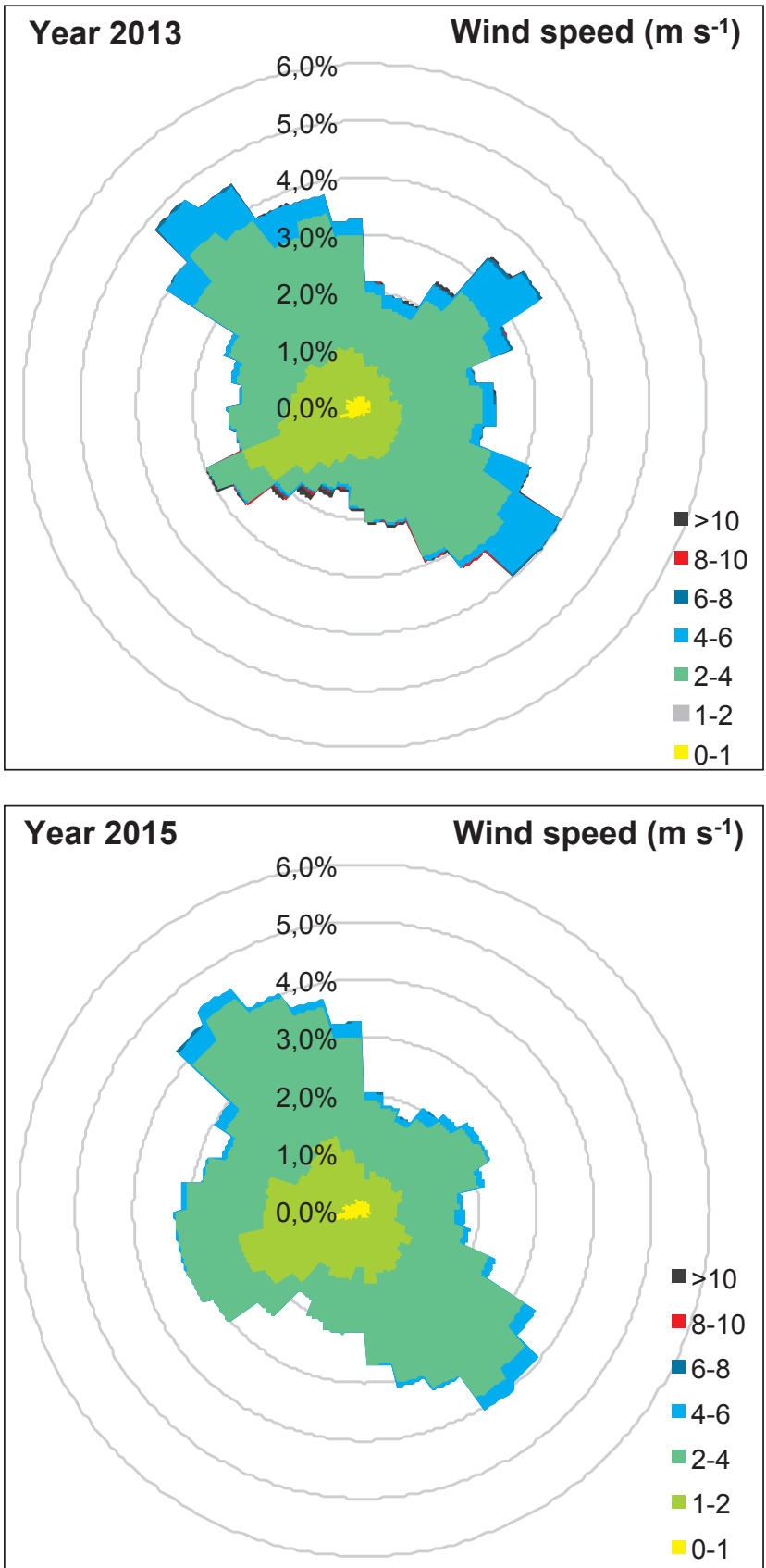

The percentage of calm conditions in the growing and non-growing season during 2013-16 was 6\% and when the data was analysed separately for day- and night-time, calmer conditions were recorded during day-time (Table 2). The reason for this is the subject of a further investigation.

\section{Conclusions}

The prevailing wind direction over the course of a year at Rajec ES was SE and NW. Seasonal shifts in the prevailing wind directions were recorded in all four years. During winter, the wind came predominantly from the SW and NE and shifted during spring and summer to NW, N, NE. Main wind directions during autumn were SE, N, NW.
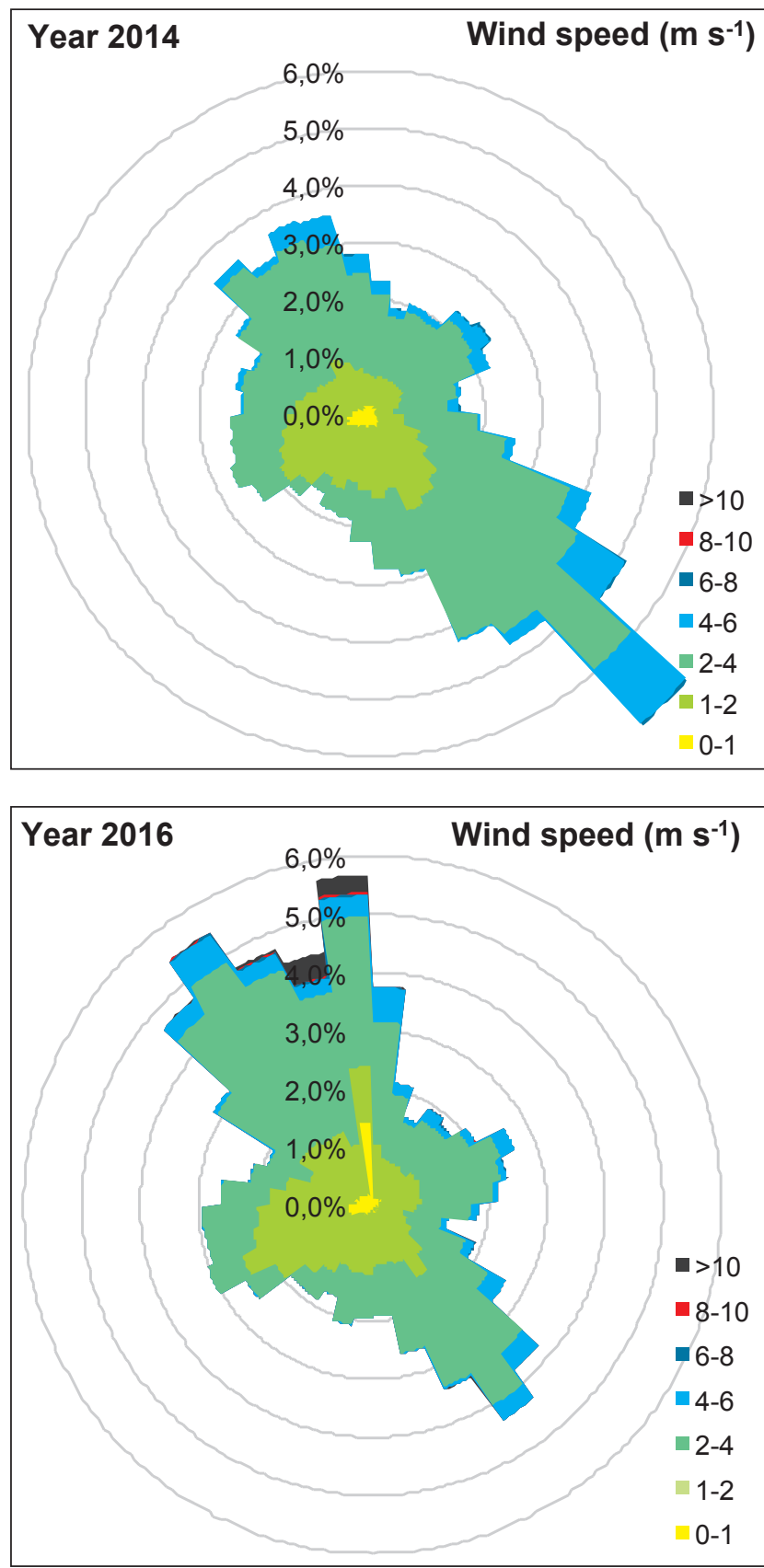

Fig. 2 Annual wind roses recorded at the Rajec ecosystem station (2013-16). 

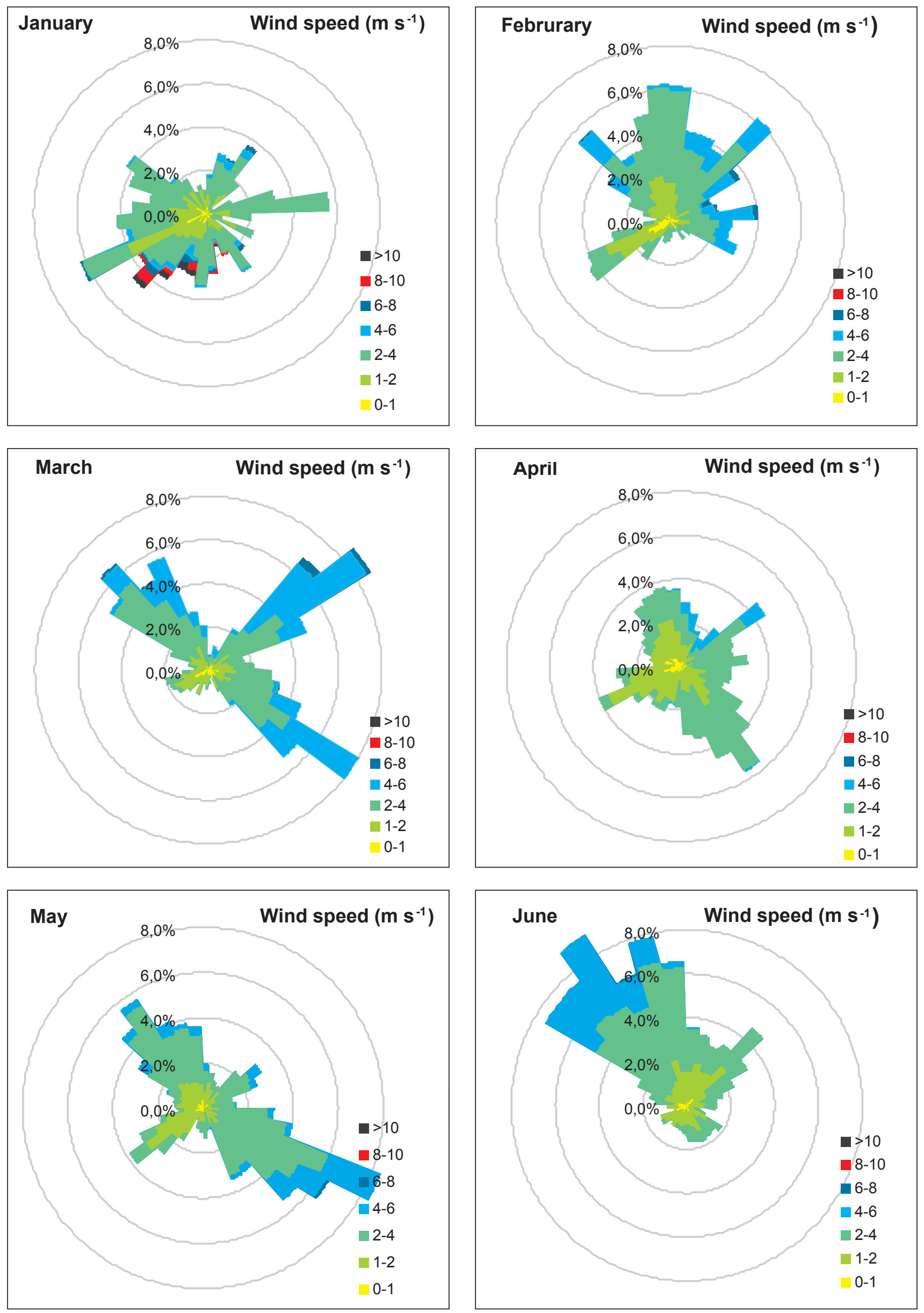

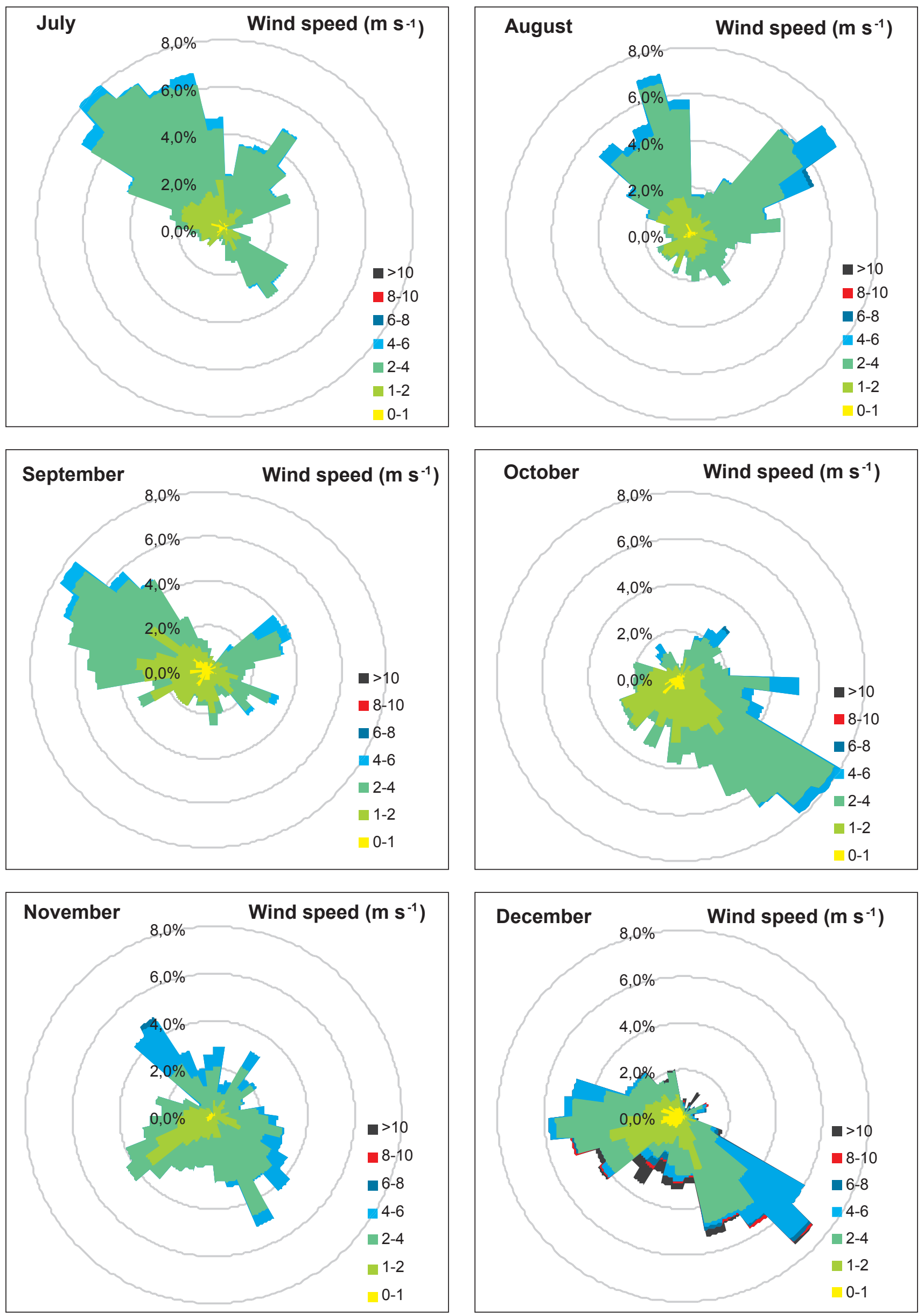

Fig. 3 Monthly wind roses recorded at Rajec ecosystem station during the year 2013. 

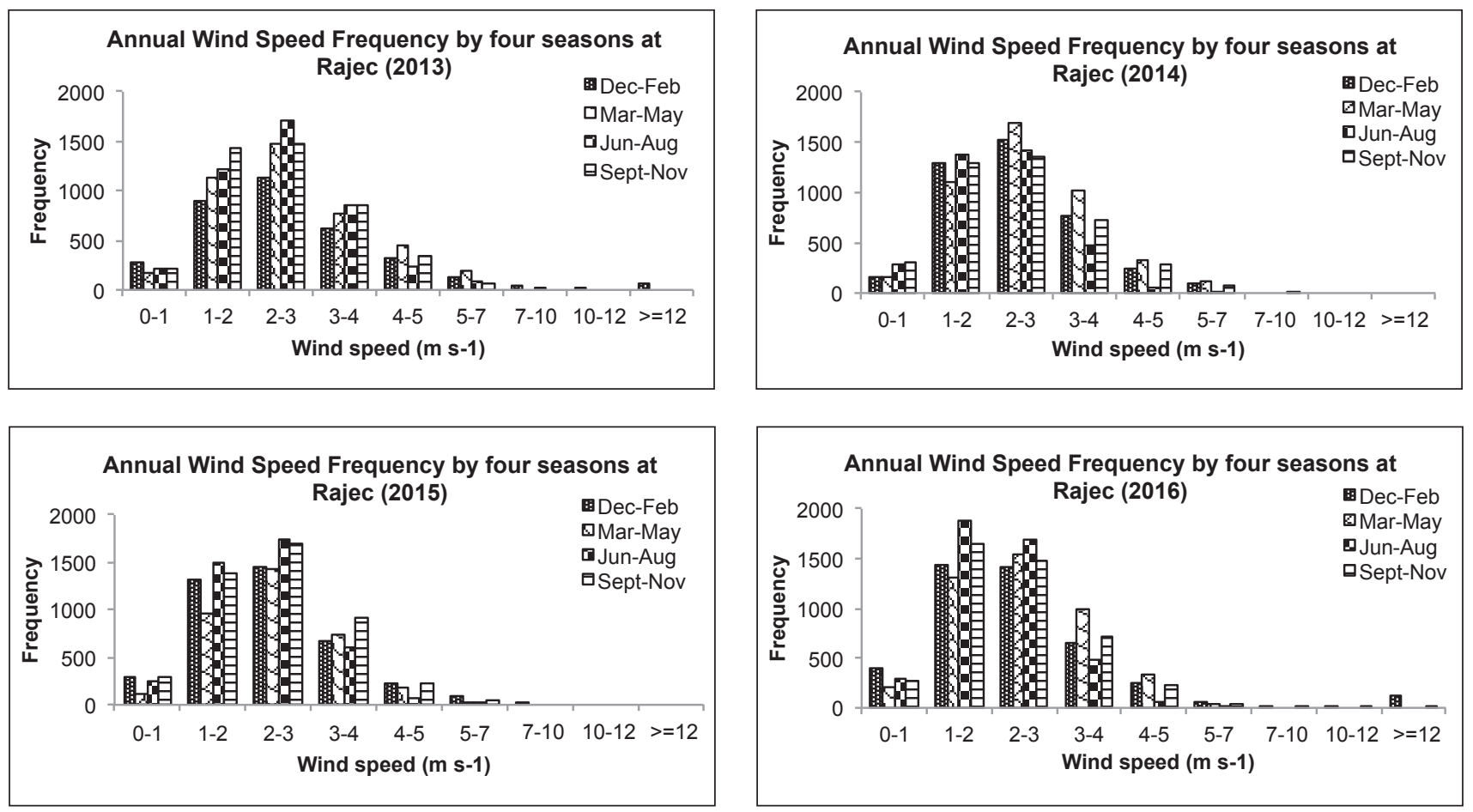

Fig. 4 Annual Wind Speed Frequency recorded in four seasons at the Rajec ecosystem station.

The wind analysis at Rajec corresponds well with those of nearby stations (Kucharovice, Svratouch, Brno). Since the nearby World Meteorological Organization (WMO) stations are open terrain stations with a minimum influence of local topography on wind patterns, we can conclude that the local orography at ES Rajec has very little influence on the wind patterns recorded there. The shift in wind direction during the year at Rajec is determined more by changes in the general circulation patterns over the seasons.

The analysis of the winds recorded at Rajec ES indicates that there are only short periods with strong winds $\left(>10 \mathrm{~m} \mathrm{~s}^{-1}\right)$ that pose a threat to the forests in this area. Over the long term, climate change scenarios indicate an increase in extreme weather phenomena; therefore, management practices like thinning and restoration of forest need to consider the prevailing wind directions in order to increase the sustainability of the forest.

The percentage of periods with calm wind conditions (threshold value of $\mathrm{u}<1 \mathrm{~m} \mathrm{~s}^{-1}$ ) at Rajec ES is relatively low, an average of $6 \%$ for all the years included in this study. The most common range in wind speed per year is $1-3 \mathrm{~m} \mathrm{~s}^{-1}$, followed by $4-5 \mathrm{~m} \mathrm{~s}^{-1}$. Wind speeds above $10 \mathrm{~m} \mathrm{~s}^{-1}$ are not usual at Rajec ES. The observed wind conditions at Rajec ES favour the application of the EC method. These wind conditions generally result in a good mixing of the air masses across the forest canopy, which may account for the high quality the EC data and considerable reduction in the potential bias in the derived fluxes. The knowledge of low wind conditions and frequency of their occurrence help to identify problematic periods for EC measurements, which may arise due to low atmospheric turbulence.
On average over the course of the four years of this study, calmer conditions were more frequently recorded during daytime than night-time, which contrasts with most of the eddy covariance study observations at other sites (Burba 2013). The evaluation of the reasons for this observation is beyond the scope of the current study.

\section{Acknowledgements}

This work was supported by the Ministry of Education, Youth and Sports of CR within the National Sustainability Program I (NPU I), grant number LO1415.

\section{REFERENCES}

Burba G (2013) Eddy Covariance Method for scientific, industrial, agricultural and regulatory applications A Field Book on Measuring Ecosystem Gas Exchange and Areal Emission Rates LICOR Biosciences, Lincoln, NE, USA.

Cremer KW, Borough CJ (1982) Effects of stocking and thinking on wind damage in plantation. NZ J Forestry Sci 12: 244-68.

Gardiner BA, Stacey GR, Belcher RE, Wood CJ (1997) Field and wind tunnel assessments of the implications of respacing and thinning for tree stability. Forestry 70: 233-52.

Hajkova L, Vozenilek V, Tolasz R, Kohut M, Mozny M, Nekovar J, Novak M, Richterova D, Striz M, Vavra A, Vondrakova A (2012) Atlas of the phenological conditions in Czechia. Cesky Hydrometeorologicky Ustav. Olomouc, Czech Republic.

Havrankova K, Sedlak P (2004) Wind velocity analysis for mountainous site Bily Kriz. Ecologia (Bratislava) 23: 46-54.

Mayhead GJ, Gardiner JB, Durrant DW (1975) A report on the physical properties of conifers in relation to plantation stability. 
UK Forestry Commission, Research and Development Division Report.

Markova I, Pavelka M, Taufarova K, Krejza J, Janous D (2017) Meteorological Yearbook 2013. Centrum Vyzkumu Globalni Zmeny AV CR, v.v.i., 2017, pp 124.

Tolasz R, Brazdil R, Bulir O, Dobrovolny P, Dubrovsky M, Hajkova L, Halasova O, Hostynek J, Janouch M, Kohut M, Krska K, Krivancova S, Kevton V, Lepka Z, Lipina P, Mackova J, Me- telka L, Mikova T, Mrkvica Z, Mozny M, Nekovar J, Nemec L, Pokorny J, Reitschlager JD, Richterova D, Roznovsky J, Repka M, Semeradova D, Sosna V, Striz M, Sercl P, Skachova H, Stepanek P, Stepankova P, Trnka M, Valerianova A, Valter J, Vanicek K, Vavruska F, Vozenilek V, Vrablik T, Vysoudil M, Zaruba J, Zuskova I (2007) Atlas Podnebí Česka (Climate atlas of Czechia). Czech Hydrometeorological Institute, Palacky University, Olomouc. 